\title{
Pacto com o diabo: Divórcio, de Ricardo Lísias, como manual para compreender a autoficção contemporânea
}

\author{
Willian Vieira ${ }^{1}$
}

\begin{abstract}
À quoi renvoie "pacte"? Sans doute à une idée juridique de "contrat", mais évidemment on pense aussi à une alliance mystique ou surnaturelle - à un "pacte avec le Diable", qu'on signerait de son sang...
\end{abstract}

Philipe Lejeune

Divórcio (Lísias, 2013a) é um romance sobre a vida de um escritor em crise e a literatura que brota desse embate. Mas quem? Quando o nome que assina o livro sob a rubrica romance/fiç̧ão surge no texto em primeira pessoa, assim como em textos paralelos a ele ligados e que mesclam indissociável e deliberadamente a vida do autor, a do narrador e a do protagonista - canalizando para o real/biográfico o que o gênero romance costumava manter na prateleira do estritamente imaginário -, que tipo de operação estética oferece-se à leitura? Essa é só a primeira questão que atrai o leitor e o convida a seguir as pistas de um discurso sobre uma identidade estilhaçada.

A homonímia autor-narrador-personagem continua sendo o bastião do "pacto autobiográfico" (Lejeune, 1975, p. 13) e ainda norteia a discussão sobre as escritas de si, incluindo a autoficção. ${ }^{2}$ Mas, além da onomástica ontologicamente problemática, descortina-se um embate narrativo complexo, que testará, na leitura, outros problemas - dos quais o limite da literatura em sua relação com a realidade é o mais cabal. O que tentarei mostrar é que, a partir de um pacto, quiçá mefistofélico, com o autor, o leitor de Divórcio aceita invadir o âmbito do estritamente privado como experiência estética, ainda que seja para negá-la ou criticá-la depois. Afinal, o preço ético a pagar é quase nulo: tal suspensão faz parte da literatura que se vende como vanguarda ontológica.

\footnotetext{
${ }^{1}$ Doutorando do programa de Estudos Linguísticos, Literários e Tradutológicos em Francês da Universidade de São Paulo (USP), São Paulo, SP, Brasil. E-mail: vieira.will@gmail.com

${ }^{2}$ O termo, surgido na França em 1977 com o livro Fils, de Serge Doubrovsky, tornou-se consensual para definir a literatura calcada no cruzamento deliberadamente confuso entre realidade e ficção. Na contracapa, Doubrovsky a definia como "ficção de eventos e fatos absolutamente reais".
} 


\section{Os signos da autoficção, didaticamente escancarados ao leitor}

A dimensão narrativa do $e u$ aparece na sétima palavra de Divórcio (Lísias, 2013a, p. 7), na conjugação do verbo achar: "achei que tivesse morrido". A 12a é corpo: "meu corpo". O narrador-protagonista descreve o estado de angústia e perda de sentido no qual se sente "sem pele". A empatia pelo relato de uma experiência (logo, em algum âmbito, real) é imediata. Ele expõe fraqueza e sofrimento, clama por compreensão, pontua a cada frase o que sente, o que pretende fazer para deixar de sentilo, como quer vingar-se e como o fará. Explicando ao leitor seu projeto de vida e de livro, o narrador ganha um aliado. Esse poderia, assim, ser só mais um narrador homodiegético de um romance qualquer. Até que, em itálico, surge o trecho de um diário e o nome Ricardo.

NY, 14 de julho de 2011 (no hotel Riverside)

Apesar de andar muito, o Ricardo é legal. Ele é uma boa companhia: é engraçado e de vez em quando inteligente. É que as vezes (sic) nos intervalos das caminhadas que ele quer fazer o tempo inteiro ele diz coisas inteligentes. Mas eu também não entendo: ele se recusa a ver uma peça da Broadway! Os grandes autores do mundo passaram pela Broadway, mas não adianta dizer isso. Ele não dá atenção. Mas a viagem está servindo pra me mostrar que apesar disso eu casei com o cara certo pra mim. Só que apaixonada eu não estou (Lísias, 2013a, p. 10-11, grifo nosso).

A partir daí, os índices de referencialidade se seguem vertiginosamente. Na p. 13, o narrador se revela escritor e sugere a relação entre um texto real e a obra ficcional nas mãos do leitor. ${ }^{3}$ Depois, menciona um dos personagens do Lísias autor ${ }^{4}$ e emenda: "Apaixonei-me pela minha ex-mulher no dia do lançamento de O livro dos mandarins. ${ }^{5}$ Não aconteceu nada: ela não escreveu esse diário e não

\footnotetext{
${ }^{3}$ No trecho, fica clara a ideia de que há intertextualidade: "Eu acabara de escrever um SMS chamando minha mulher de puta quando, na metade de uma frase autobiográfica, achei que estava vivendo um dos meus contos. Com certeza eu assinaria essa história" (Lísias, 2013, p. 15, grifo nosso).

${ }^{4}$ No caso, o personagem Damião, de um dos contos reunidos em Concentração e outros contos (2015). Já na p. 36 de Divórcio, "meu amigo André" é mencionado ao falar de morte. Ele é o personagem de $O$ céu dos suicidas. O personagem reaparecerá outras vezes ao longo do romance. $\mathrm{O}$ narrador mencionará ainda, na p. 109, como sendo seu Cobertor de estrelas (p. 149), outra obra de Lísias autor.

${ }^{5}$ Outro livro do autor que assina Divórcio.
} 
cobriu o Festival de Cannes de 2011 para um jornal. É só um conto" (Lísias, 2013a, p. 13). Na sequência, diz ainda "Só pode ser ficção. No meu último romance, $O$ céu dos suicidas, o narrador enlouquece e sai andando. Agora, fiquei louco e estou vivendo minhas personagens" (Lísias, 2013a, p. 13).

Em suma, estão aqui as referências ao nome do autor/narrador/personagem, o caso mais tradicional da homonímia autoficcional; à profissão de escritor; ${ }^{6}$ às obras ficcionais publicadas pelo autor real (que figuram na orelha do livro, permitindo seu cotejamento), aqui atribuídas ao narrador-protagonista; à veracidade dos nomes; ${ }^{7}$ ao gênero em si, fixado entre os termos "nota autobiográfica", "conto", "ficção" e "diário", e mesmo a distinção do registro tipográfico, com trechos narrados por outra pessoa, a ex-mulher, italicizados, enquanto a voz protagonista da história segue em fonte normal. Isso sem mencionar os paratextos, inclusive imagéticos, como se verá a seguir, e seu papel para a indecidibilidade estatutária do texto e de seu narrador.

Divórcio poderia, assim, servir como uma espécie de manual sobre a autoficção contemporânea, para autores e leitores, especialistas e leigos. Outros o fazem de forma mais sutil, complexa. Lísias, em nove páginas, entrega de forma mastigada as chaves para compreender e entrar em seu jogo literário. A partir daí, o leitor já se sabe presa de uma teia discursiva que impedirá qualquer distinção definitiva entre realidade e ficção, biografia e imaginação. E sabe que, muito além da dor da traição e do divórcio do título, esse é o cerne da obra: testar os limites do testemunho e da confissão na ficção.

\section{Estatuto, contrato, pacto de leitura: a dúvida como norte da recepção}

A noção de pacto de leitura, antiga e cara às teorias da recepção, ganhou força com os estudos sobre autobiografia. Assim, convencionou-se que, a partir de um "contrato de leitura" (Lejeune, 1975 , p. 8), um texto seria lido numa chave específica, estabelecida em comum acordo entre autor e leitor, com base, sobretudo, na percepção

\footnotetext{
${ }^{6} \mathrm{Na}$ página 60, o narrador se dirá "professor de gramática de língua portuguesa em um centro universitário especializado em tecnologia", também ocupação do autor, segundo entrevistas suas.

${ }^{7}$ Por exemplo, a ex-mulher (e outros personagens) não tem nome, pois o epíteto é mantido; os amigos cujos nomes aparecem ganham nomes reais; personagens sem nome ou epíteto são referidos por [X].
} 
da exata identidade entre autor, narrador e protagonista. Ao retomar tal debate, Helmut Galle lembra que "o autor sugere aos seus leitores: eu, que escrevo isso, sou o mesmo que vivenciou os acontecimentos narrados" (Galle, 2011, p. 68). Dessa forma, caberia ao leitor observar os paratextos e suas implicações para essa identidade entre autor e narrador (p. 75), a fim de "realizar a leitura 'adequada', isto é, a leitura que permite processar as asserções feitas no texto da forma que o autor considerou proveitosa" (Galle, 2011, p. 68).

Como fica essa "leitura adequada", porém, quando o quadro lejeuniano já não dá conta de abarcar, ao mesmo tempo, a onomástica exata e um paratexto sugerindo ficção? Por exemplo, quando a história ganha o suplemento de verdade de um paratexto como o que segue, à guisa de apresentação de Divórcio em sua contracapa?

Agosto de 2011. Casado há quatro meses, o narrador de Divórcio encontra acidentalmente o diário da esposa em que, entre outras coisas, ela escreve: O Ricardo é patético, qualquer criança teria vergonha de ter um pai desse. Casei com um homem que não viveu. "Depois de quatro dias sem dormir, achei que tivesse morrido", ele desabafa. A partir de então, descreve seu desmoronamento e a tentativa de compreender o que o levou ao ponto crítico. A literatura e os treinos de corrida cada vez mais intensos servem para que alguma lucidez retorne à sua vida. Mas nem sempre é possível explicar friamente o que ocorreu, dar ordem aos sentimentos conflitantes, à dor e à obsessão, ao desejo de esquecer. É isso o que torna Divórcio um romance sem paralelos. Num fluxo emocionante, numa reconstrução ficcional da memória, o autor ultrapassa os limites da autoficção e alcança um novo terreno, em que a literatura - a literatura combativa, desafiadora - tem a última palavra (Lísias, 2013a, s.p., negrito nosso).

Subentende-se que o autor, via uma "reconstrução ficcional da memória" (uma memória real), "ultrapassa os limites da autoficção" (logo, da ficcionalização da vida real) e "alcança um novo terreno", espaço romanesco aberto, terreno de uma literatura "combativa" - ou, como veremos, de vingança. Assim, a ficcionalidade antes assumida pelos paratextos (a rubrica romance) ou procedimentos específicos de narração (como o discurso indireto livre) fica suspensa.

Recorrendo ao livro em mãos, que pacto se estabelece entre autor, narrador e leitor? Que contrato surge desse protocolo genérico que 
serve de manual de leitura, não no sentido de instruí-la segundo um estatuto narrativo específico, mas, ao contrário, como elemento complicador, de forma a "intensificar a indefinição do gênero e a confusão de planos no leitor" (Alberca, 2007, p. 256) ? ${ }^{8}$ Se o leitor encontra já na teia paratextual não apenas a biografia do autor (com sua bibliografia idêntica à do narrador/protagonista), mas a rubrica "romance" aliada à autoficção - gênero epistemologicamente incerto, localizado numa fronteira movediça que flerta com o escândalo e o sofrimento alheio -, como procede?

Gerard Genette, ao parir um esquema de pactos possíveis, afirma que, no caso da autoficção, caberia ao leitor a investigação das contradições para poder estabelecer seu estatuto (Genette, 1991, p. 8889). A própria classificação paratextual como autoficção instigá-lo-ia a tornar-se um investigador. O que significa "que a leitura e a interpretação se tornam ambíguas para os casos nos quais a relação entre autor e narrador foi intencionalmente deixada em ambiguidade" (Galle, 2011, p. 78). Assim, haveria um "pacto paradoxal" (Galle, 2011, p. 108) que, em vez de servir para situar o leitor, o confunde deliberadamente. No caso de Divórcio, em que o estatuto do texto e a natureza do pacto referencial seguem embaralhados, sobretudo pelas referências ao autor real identificáveis ${ }^{9}$ e a um diário íntimo ao qual ele ganha um acesso indevido em qualquer esfera que não a ficcionalliterária, repito: como procede o leitor?

Se já não basta apelar à ficcionalidade inalienável da literatura para definir um contrato ficcional de leitura, o que dizer do pacto estabelecido entre autor e leitor nas condições descritas, onde todo esforço para aproximar vida pessoal do autor (e logo o estatuto de verdade do texto) da recepção do leitor é realizado, dentro

\footnotetext{
${ }^{8}$ Divórcio cabe na definição de Alberca (2007, p. 181-182) quando, ao estabelecer uma tipologia das autoficções segundo sua tendência (mais próxima do pacto autobiográfico ou, ao contrário, do novelesco-ficcional), chama de "autoficção biográfica" o romance cujo "ponto de partida é a vida do escritor que resulta ligeiramente transformada ao inserir-se em uma estrutura novelesca, mas sem perder a evidência biográfica em nenhum momento". O foco seria a insistência da estratégia (extra e intratextual) de aproximar autor e narrador sem garantia de identificação (administrativo-legal) num jogo que, dado o baixo grau de ficcionalização percebido pelo leitor, funciona como máscara deliberadamente insuficiente ou "calculada estratégia para autorrepresentar-se de maneira ambígua".

${ }^{9}$ Na página 66, há o trecho do que seria um e-mail ao advogado da ex-mulher, que finda assim: "Um abraço, Ricardo Lísias". Na p. 78, lê-se: "Quando o medo de ter enlouquecido ficou muito forte, parei em um sinal vermelho e repeti o meu nome. Ricardo Lísias. O meu nome é Ricardo Lísias."
} 
(formalmente, no relato em primeira pessoa, e rematicamente, nas referências verificáveis) e fora do texto (paratextos)? Isso para se ater apenas ao volume físico do livro. Porque, como se verá, esse autornarrador-personagem ganha outros discursos que cercam o leitor.

\section{Paratextos, epitextos, intertextos: o autor além do espaço do livro}

A partir da décima página de Divórcio, um leitor curioso, se ainda ignorante do tipo de produção que tem em mãos, faria uma pesquisa na internet. E Lísias é extremamente midiático. Dá entrevistas a jornais e TV, publica contos em revistas e tem uma farta conta no Facebook, onde republica todo esse material, além de textos de seu fanzine e opiniões sobre literatura. O que vai ao encontro de certa "função adicional" da autoficção, pautada pela "superação da fronteira entre obra literária e biografia do autor, ou seja, a fronteira entre arte e vida" (Galle, 2011, p. 112).

Comparando a proporção entre o tempo que o público assiste às manifestações extraliterárias de um autor e o tempo que se aplica para ler seus livros, a imagem midiática do autor começa a dominar a imagem formada a partir da obra. A autoficção pode enfrentar esse problema com uma estratégia ofensiva: apresentar uma obra que desde já não permite mais distinguir entre vida real e ficção, entre obra e realidade (Galle, 2011, p. 112-113).

Chamar de "extraliterárias", porém, manifestações que contribuem para um projeto de escrita que condiciona um tipo específico de leitura parece insuficiente no caso de Divórcio, em que a engenharia discursiva em torno da obra tem outro nível. Lísias preparou o terreno de forma exemplar. Fez circular por e-mail e via redes sociais um texto no qual expunha a intimação extrajudicial enviada pelo advogado da ex-esposa com ameaças à publicação, por parte dele, de informações de um diário que teria sido escrito por ela e encontrado e copiado por ele, além de um libelo em favor da liberdade criativa e da literatura em si. ${ }^{10}$ Pouco depois, Lísias publicou o primeiro conto ${ }^{11}$ na revista Piauí, no qual escrevia sobre o diário e ter começado a correr para suportar o divórcio.

\footnotetext{
${ }^{10}$ Nesse documento há a mesma história do romance, mas como sendo a vida do autor. Lê-se ali, por exemplo, a seguinte frase: "Xeroquei o diário para me resguardar".

${ }^{11}$ Lê-se no romance Divórcio: "Procurei os manuscritos do conto Divórcio, que eu publicaria três meses depois, e percebi que os primeiros esboços datam do sábado" (p. 77). O diálogo entre o romance e textos da vida real torna-se, como se vê, indelével.
} 
Em seguida, publicou o que seria o primeiro capítulo do livro: fez cópias e distribuiu. A versão, em pdf, foi espalhada pela internet. E publicou outro conto de teor similar na mesma revista. Com a publicidade alcançada por tais etapas, deu entrevistas à imprensa, sedenta por informações sobre o livro sendo escrito. Meses depois saía Divórcio, com boas críticas nos jornais e vendas acima da média.

Todos os textos apresentam os mesmos temas: o diário, o divórcio, a feitura da literatura a partir do trauma. Poder-se-iam chamar esses documentos de paratextuais - ou melhor, epitextuais (Genette, 1987, p. 316), na medida em que fazem parte de forma integral não só do alcance e do tom da fruição/leitura, mas da forma da própria construção do livro enquanto obra ou, ainda mais, em relação ao estatuto ficcional dos trechos do diário encontrados no livro. Mas talvez fosse mais apropriado pensá-los como "espaços escriturais" (Galíndez-Jorge, 2009, p. 84): espaços onde a escritura acontece como método em prática, projeto (literário) em andamento - e, sobretudo, visto sua publicação, como parte de uma ampla performance literária.

O que se vê acima é um processo de criação literária que trabalha em duas frentes concomitantes e interdependentes: a literária-ficcional e a biográfica-real. Ao publicar e fazer circular entre leitores de suas obras textos que tratam de circunstâncias verificáveis de sua vida, Lísias liga vida e obra de forma inextricável. $\mathrm{O}$ tal diário (real) pode ou não ser o mesmo diário (ficcional) cujos trechos existem no romance: seu estatuto textual fica em suspenso, vagando entre o espaço da obra, o diálogo midiático, a interpelação judicial e o mundo real. Para o leitor, o efeito dessa rede textual com as mesmas referências é o de uma performance autoral inalienável, que permeará o romance e a voz atribuída a esse narrador-protagonista. ${ }^{12}$

Essa voz que assume a performance ${ }^{13}$ seria, "ao mesmo tempo, sujeito e objeto de uma atitude que define a escritura como passagem do

\footnotetext{
${ }^{12}$ Outro exemplo de como a performance é central no projeto literário do autor é seu livro Inquérito policial: família Tobias (2016), feito a partir de um depoimento que se viu obrigado a prestar à polícia após denúncia anônima sobre falsificação de documentos. Não só o romance ficcionaliza tais situações mantendo a homonímia e a analogia de história de vida autor-personagem como, antes da publicação, Lísias fez circular no Facebook um vídeo em que era agredido e anunciava o livro, além de atuar como o personagem Ricardo Lísias em peça homônima ao romance, no mesmo período.

${ }^{13}$ Diana Klinger sugere que "a autoficção só faz sentido se lida como show, como espetáculo, ou como gesto" (Klinger, 2007, p. 26), ou seja, como escrita da performance, pois supõe "uma dramatização de si”, um processo de construção do outro na figura do eu que demanda, como no
} 
olhar ao espetáculo" (Blanckeman, 2000, p. 91). Passagem marcada ainda pelo signo da compressão espaço-temporal, tanto da quase consonância entre situação vivida e escrita ${ }^{14}$ como da indissociação dessa escrita entre o jornal íntimo, a narrativa autobiográfica e a autoficção como produto final. Desse ato performático-performativo surgiria uma poética nova, calcada na própria licença poética de escrever sobre o interdito, o proibido, que estabelece um diálogo engajado entre quem escreve e quem lê. ${ }^{15}$

Mas a performance não dá conta do papel tão mais ativo que exige do leitor essa literatura de si. Acrescentaríamos a noção de jogo: a autoficção é efetiva e atrai o leitor, alcança uma dimensão literária específica, se é capaz de convocar o leitor para um enfrentamento, um jogo que suspende as certezas sobre o registro de leitura. E consegue isso graças a uma poética do dizível que engendra uma nova estética da dúvida, por meio, como veremos mais adiante, de um pacto centrado na deriva ética.

\section{Jogo e "efeito de real": da referência ao real à estética da suspensão}

Roland Barthes teorizou sobre a presença de elementos sem outra função no texto além de atestar a concretude do real narrado, denotando-o e conotando-o: o famigerado "efeito de real" (Barthes, 2004 , p. 184). Penso poder subverter o conceito aplicado ao realismo francês ao aproximá-lo da autoficção atual. Não trariam as notações referentes à realidade e à materialidade corpórea do autor que se viu até aqui em Divórcio outra espécie de efeito de real? Tais notações parecem ir ao encontro de certa estética hiperrealista, ensejada pela autoficção ao exaltar "a aparência extrema do real até praticamente desrealizá-lo"

palco teatral, "um sujeito duplo, ao mesmo tempo real e fictício, pessoa (ator) e personagem" (p. 25). O sujeito autoral da autoficção "não é um "ser" pleno cuja existência ontológica possa ser provada", mas o "resultado de uma construção que opera tanto dentro do texto quanto fora dele, na "vida mesma"" (p. 24).

${ }^{14} \mathrm{O}$ crítico pensa a autoficção de Hervé Guibert, cuja postura seria frontal, o que "consiste em abordar diretamente os períodos da existência reduzindo ao máximo o tempo que separa a experiência de sua narração, uma emergência de uma vida exterior mais que lembranças de uma vida após a morte" (Blanckeman, 2000, p. 91, tradução nossa).

15 Ou seja, uma "poética do eu" marcada pela "estratégia de ambiguidade" típica da autoficção, tanto por meio do "metadiscurso interno" da obra quanto nos "discursos midiáticos" (Gasparini, 2016, p. 5, tradução nossa). 
(Alberca, 2007, p. 50), garantindo, assim, por meio de uma "estética da presentação" (Alberca, 2007, p. 51, tradução nossa), uma recepção amplificada do real projetado a partir do texto. Sem elas, Divórcio seria só mais um romance em primeira pessoa, tendo como protagonistanarrador um escritor defrontado com a tarefa de escrever sobre a própria experiência (e a literatura é fértil em romances do tipo).

Com tais referências a um real presente, íntimo, o livro ganha ares de testemunho: se não o de uma confissão (a confissão da vingança via escrita), ao menos o de uma aventura real, cujo produto jaz nas mãos do leitor. Graças a elas, o efeito de presenciar o testemunho de uma biografia o impregna, ainda mais da partir da página 150 - quando o leitor já aceitou um pacto ambíguo com essa instância narrativa confusa, que mescla a vida e a arte do autor e do narrador-personagem -, quando surge uma série de onze fotos sem legenda do autor quando criança: sua foto na contracapa não deixa dúvidas.

Além do suplemento de intimidade e realidade, tais elementos gráficos reforçam os enxertos textuais e as referências (homonímia, obras partilhadas entre autor e narrador), numa retroalimentação intertextual eterna. Se Divórcio trata de uma "reconstrução ficcional da memória", história real retrabalhada sob a égide do testemunho ficcionalizado, qual a diferença na recepção quando o leitor sente que o texto em mãos trata do real, e não apenas esquece que ele não é real - como se tornou praxe atribuir ao realismo pela noção de suspensão temporária da descrença?

O leitor da autoficção, além do efeito de real que esse dúbio hiperrealismo biográfico oferece, nutre-se ainda de outro suplemento, de cunho ético-estético: o direito de poder esquecer que o que lê é real mesmo sabendo-o, em última instância -, podendo fruir a ficção como um suplemento de verdade eticamente indecifrável. Quando, alfinetado pelas referências da realidade, fuça na intimidade alheia, não só do autornarrador-personagem que se projeta, como na de terceiros, não precisa desculpar-se: o suprassumo da experiência estética jaz justamente nessa suspensão ética atrelada à suspensão estatutária do texto. Afinal, a literatura oferece ao leitor tais "experiências substitutas", "experiências que, por serem incorporadas em ontologias artisticamente moldadas, elevam nossa consciência de discriminações morais" (Schwarz, 2001, p. 5).

O leitor contemporâneo - acostumado a diferenciar textos que fazem referência à realidade (como os históricos e autobiográficos) dos que 
seriam puro produto da imaginação, que nos permitem momentos de crença voluntária numa realidade fictícia sem consequências à vida real -, quando exposto à suspensão estatutária violenta de Divórcio, tem a chance de se imiscuir na vida íntima de alguém que pode ser real. É quando tais "consequências" tornam-se claras. Supor que a questão ética não norteia a recepção de um livro que deliberadamente embaralha o estatuto textual ao passo que semeia o texto de referências, que seja secundárias em relação à ficção, é ingenuidade.

Como sugere Pedro Meira Monteiro, "se déssemos por certa a inexistência do diário, a máquina das questões éticas se desligaria, ou se tornaria mais débil" (Monteiro, 2013, p. 165). Mas isso não é possível, dada a bagunça estatutária do romance. Sobram, então, perguntas: "que pode fazer a ficção com aquilo que não é ficção? Até onde podemos ir os narradores que sempre somos quando contamos uma história - nessa aproximação do mundo não ficcional?" (Monteiro, 2013, p. 163). ${ }^{16}$ A ética, aqui, é central. E por razões estéticas.

\section{O jogo estético da ambiguidade: metaficção e estatuto ficcional}

Foi dito que Lísias, já no início do livro, lança ao leitor as chaves para compreender sua autoficção comme il faut. Mas novas chaves de compreensão serão oferecidas ao longo da obra, sendo a principal delas a que dá certa especificidade ao romance: sua indefinição estatutária transformada em jogo ético-estético.

Vários elementos sustentam essa impressão. Vide a relação que se instaura entre os trechos do diário, italicizados, imbuídos da função pragmática inicial (ou seja, de um caráter proibitivo: o diário, escrita íntima, surge como resultado de um roubo, ou, no mínimo, de um voyeurismo explícito) e o texto principal. A partir da metade do livro, eles se mesclam e as frases do diário surgem repetidas, não italicizadas, na voz do narrador. Os trechos seguintes dão mais força aos fragmentos do diário, ao definir (ainda que, a princípio, apenas no simples nível da diegese) um estatuto ficcional e outro referencial aos trechos do diário nos contos que alimentaram o romance:

\footnotetext{
16 "Mas a literatura de Ricardo Lísias vive exatamente do embaralhamento e da vertigem que nos toma sempre que nos sabemos demasiado próximos da realidade. Aí estão os limites que a ética deve explorar, mas está também o alcance político da ficção, que interpela vivos e mortos, para não deixá-los jamais à vontade" (Monteiro, 2013, p. 165-166).
} 
Quando as pessoas souberem quem de fato é essa mulher, vão no mínimo querer cuidar de mim. Para isso, planejei colocar entre os parágrafos do novo conto trechos refeitos (mas com o mesmo sentido) do diário (Lísias, 2013a, p. 164).

Resolvi me certificar e duas outras pessoas, entre as tantas que estavam inundando a minha vida de fofoca, foram atrás da informação e de fato voltaram dizendo que ela tinha mesmo jogado o diário fora. Não tive dúvidas, então: descartei a minha redação e no conto "Meus três Marcelos", simplesmente reproduzi alguns trechos do diário da minha ex-mulher (Lísias, 2013a, p. 171, grifo nosso).

Uma relação dialógica se instaura entre dois níveis de registro: as "notas autobiográficas" que o narrador diz retomar em sua pesquisa por memória para escrever o romance e o relato em tom de testemunho/relato autobiográfico narrado no livro. Quando diz: “Ontem, quando fui preparar esse trecho (escrevo logo depois de acordar, mas deixo tudo arranjado no dia anterior), reli uma parte do que escrevi naquele período" (Lísias, 2013a, p. 49), ${ }^{17}$ o grau de intimidade do leitor com a obra sendo escrita lembra Memorial de Aires, de Machado de Assis, por exemplo. Pois não é nova a técnica de mostrar o livro sendo escrito em presença do leitor. O que é novo é a suspensão do estatuto ficcional elevar o efeito dessa intimidade ao infinito.

O narrador mantém ainda marcadores espaço-temporais críveis: frases como "Estou escrevendo onze meses depois de ter saído de casa" (Lísias, 2013a, p. 49) juntam-se a menções sobre onde e como está escrevendo qual trecho do livro atual, dando a noção exata de um percurso de escrita que representa uma experiência de vida real. ${ }^{18}$ Há ainda a relação, tipicamente realista, entre a narrativa e fatos históricos comprováveis $^{19}$ e entre textos ficcionais publicados a partir do divórcio

\footnotetext{
${ }^{17}$ Em outro trecho, diz o narrador: "Estou redigindo a primeira versão desse capítulo em maio de 2012" (p. 120). E, logo: "O capítulo fracassou. Meu plano inicial era lembrar tudo o que vivi de bom com minha ex-mulher para entender porque resolvi me casar" (p. 131).

${ }^{18}$ Por exemplo, quando o narrador diz, pontuando o momento exato da gênese do romance em curso: "A seguinte frase me mostrou que eu precisava fazer um romance: onde é que as pessoas chegam?” (p. 172)

19 "Minha ex-mulher estava na plateia da entrevista em que Lars von Trier, a despeito de apresentar Melancolia, disse ser meio nazista e entender Hitler. A situação é mais embaraçosa porque em momento algum ele aparenta ter perdido inteiramente o controle. Ao menos no início, antes de tudo virar uma bola de neve, o cineasta parece debochar de alguma coisa. Assisti à entrevista dezenas de vezes. A última foi ontem, quando esquematizei esse fragmento" (p. 112, grifo nosso).
} 
(dois contos na revista Piauî. ${ }^{20}$ Interessante notar ainda que tais referências tecem um discurso paralelo, de cunho autobiográfico pseudo-intraficcional, que só corrobora a percepção pelo leitor de um autor real que se entrega e de uma intimidade sem limites, uma parceria, um pacto. ${ }^{21}$ Mas um pacto volúvel, dadas as pistas plantadas ao longo do texto, que servem como chaves de compreensão do estatuto do diário e da narrativa em torno dele. O trecho seguinte, por exemplo, parece jogar a pá de cal sobre a definição estatutária:

Ainda que eu me contradiga em outro lugar desse texto e no que eu possa eventualmente dizer sobre essa merda toda em que me joguei, o diário que reproduzo aqui é sem nenhuma diferença o mesmo que xeroquei antes de sair de casa. Aliás, não há uma palavra de ficção nesse romance (Lísias, 2013a, p. 172, grifo nosso).

Vale compará-lo a outro momento, páginas antes, quando, após ter afirmado que a esposa era a jornalista que cobrira o festival de Cannes para o jornal no ano específico, crava: "Não estou tratando de uma pessoa em particular. Minha ex-mulher não existe: é um personagem de romance" (p.128). Parece, aqui, que o narrador/autor joga a última pedra sobre o pacto referencial-ficcional e, ao mesmo tempo, ajuda a se proteger de um processo judicial. ${ }^{22}$ Mas os trechos fazem parte, na verdade, de uma rede de afirmações e negações que o narrador-protagonista, homônimo do autor, efetua com o intuito de confundir - como se instaurasse no seio mesmo do texto uma dialética com um prólogo ou prefácio imaginário, anunciando dentro do romance o pacto de verdade a ser seguido, mas mudando de posição o tempo todo.

Mais do que insinuar uma metafição (que fica evidente a partir da página 195, quando o escritor passa a falar de Divórcio com tal título, elencando seus erros e limitações), o procedimento decreta a ambiguidade perene por parte do autor. Tal vaivém, repleto de afirmações antitéticas, faz

\footnotetext{
${ }^{20}$ Como se vê no trecho a seguir: "Quando faltavam duas semanas para terminar o curso de contos e "Meus três Marcelos" já estava na metade, finalmente o primeiro texto que escrevi sobre tudo isso, "Divórcio", foi publicado (p. 165).

${ }^{21}$ Como se o leitor acompanhasse a formação biográfica paulatina do escritor, seu diário de desvios não ficcionais, sua projeção intencional em migalhas de realidade entrelaçadas à ficção. Por meio da construção de um mito pessoal de estatuto duvidoso, a história de vida se complementa. Afinal, o narrador comenta a própria obra o tempo todo.

${ }^{22}$ Algo comum com livros autoficcionais. Christine Angot, por exemplo, foi condenada duas vezes.
} 
parte não apenas do jogo autor-leitor em busca do estatuto perdido como de uma construção da personalidade frágil e pouco confiável de um narrador-protagonista em agonia, que, por pouco fiável, ajudaria a enfraquecer ainda mais qualquer certeza em relação ao pacto.

Como um Pôncio Pilatos em looping, ele joga com o leitor ad infinitum, de forma a construir uma personalidade narrativa cuja enunciação não permite uma certeza estatutária - o que, por sua vez, comprovaria um desvio ético/jurídico - ao mesmo tempo que costura uma sempiterna dialética entre o texto, sua escrita (como tema e como prática) e suas referências, abrindo, por meio de um "autobiografismo à la carte" (Alberca, 2007, p. 291), ${ }^{23}$ as portas para a total autonomia do leitor em decidir sua chave de leitura.

\section{A figura do autocomentador e a defesa da autonomia do fazer literário}

"A maneira com que qualquer leitor interpreta o meu livro é de responsabilidade dele próprio" (Lísias, 2013b). A frase vai ao encontro do debate corrente norteado pela noção renovada de autonomia plena da literatura em (d)escrever o real - é a resposta de Lísias à pergunta feita por Luciano Trigo, em entrevista, à época do lançamento de Divórcio. O jornalista polemizava a relação entre realidade e ficção que, como se verá, já permeava a feitura do livro segundo sua divulgação. Lísias se viu às voltas com tais questões não à toa. ${ }^{24} \mathrm{~A}$ entrevista era o corolário de um projeto literário no qual imprensa, mercado editorial e academia (e, quiçá, até a justiça) têm lugar essencial. Um projeto que parece retomar a tradicional função-manifesto do romance, ao repensar nele as distinções entre romance, autobiografia e ensaio, "fazendo do texto sua própria teoria" (Blanckeman, 2012, p. 29). Daí o passo seguinte na análise atual: a autoficção, como atesta o romance de Lísias, do ponto

\footnotetext{
${ }^{23}$ O termo daria conta da fuga "dos desafios de sinceridade e ética" (Alberca, 2007, p. 291) e da perda de legitimidade literária que, segundo o crítico, tem relação com a noção de autobiografia strictu sensu.

${ }^{24} \mathrm{O}$ escritor tergiversou. "Não tenho nenhum interesse por nada que não seja literatura [...]. Como eu disse, cada leitor é livre para fazer a própria leitura. A literatura - e de novo a arte de maneira mais ampla - não é capaz de reproduzir a 'realidade'. Assim, nenhum romance 'expõe' a vida de seu autor ou de qualquer outra pessoa, mas sim cria personagens e situações ficcionais. [...] Não creio que a literatura se refira em nenhum grau à 'vida' de seu autor ou de quaisquer outras pessoas” (Lísias, 2013b, s.p.).
} 
de vista da enunciação, encontra-se no entrecruzamento de três discursos: o autoral, o crítico-acadêmico ${ }^{25}$ e o midiático.

Em Divórcio: o passo a passo da elaboração do livro, com publicações oficiais e marginais de pedaços da obra e comentários sobre sua feitura (assim como da vida do autor, presentes em entrevistas e na circular), mescla-se às críticas feitas sobre o livro publicado e às entrevistas que o autor deu à imprensa, arvorando-se o direito de opinar sobre a literatura, além de fazê-la. O livro, a vida do escritor e a ontologia da própria literatura tornam-se indissociáveis para o leitor. Afinal, tal literatura não é só uma escrita, como o diário transformado em literatura; é, acima de tudo, uma literatura que se pensa como processo questionando seu próprio estatuto e dele fazendo uso para se promover, escrita cuja metaescrita em performance é central para seu devir.

Com um suplemento institucional em jogo, o escritor midiáticoacadêmico surge como sucedâneo da impossibilidade de atestar a origem e os estatutos discursivos na vida e na arte. É uma figura atraente. Afinal, "ao leitor produz fascinação e interesse assomar a um mundo cerrado, secreto ou proibido para aceder, finalmente, ao romper as resistências, ao espaço velado do indizível" (Alberca, 2007, p. 80). E, assim, a literatura confunde-se, deliberadamente, com sua história e deontologia. A "crônica da vida das letras" (Burgelin, 2010, p. 63) confunde-se com a crítica da obra e a teoria por trás do método: a obra problematiza a vida do escritor; sua vida problematiza a obra, num ciclo eterno de indecidibilidade que tem o leitor como juiz e voto de Minerva.

De certa maneira, o melhor critério para se definir a autoficção deve-se à superposição de quatro instâncias: a personagem, $\mathrm{o}$ narrador, o autor e o autocomentador, entre os quais se introduz um pouco de jogo, engenhosamente mantido (Burgelin, 2010, p. 64, tradução nossa).

A dimensão do romance não é dada a priori: ela se faz no terreno da paratextualidade, do comentário, da referência e sua negação - enfim, do jogo enunciativo, da performance para o leitor dentro e fora do livro. E a esse testemunho da vida vivida e vertida em literatura em

\footnotetext{
25 "O compartilhamento de experiências psicologicamente violentas, como se sabe, tem ação terapêutica também, já que transfere um dano de início individual para o coletivo, tornando-o, assim, um acontecimento social e, mais além, político". Quem afirma é Ricardo Lísias, o acadêmico, pós-doutorando em literatura, em um artigo sobre testemunho e literatura publicado na revista Estudos de Literatura Brasileira Contemporânea (Lísias, 2016, p. 229).
} 
presença (e no presente) do leitor junta-se a defesa de uma noção ontológica de literatura, seu dever, seus limites. Defesa que, no caso de Lísias, aproxima-se do libelo. ${ }^{26}$ Passionais, o tom e a forma de Divórcio vão ao encontro da vingança como tema, paroxismo desse pacto com o diabo via leitura, que estaria no nível do factual, assim como na maneira de conduzir a narrativa. Lísias escreve um libelo contra a falta de ética da ex-mulher jornalista e, logo, do jornalismo e do mundo que o cerca. A ética, na narrativa erodida por parte da mulher, termina de ser esfacelada pela voz do narrador, quando diz: não há de sobrar nada além de literatura.

Não há verdadeiro na arte. Mas há o impacto do suposto real ficcionalizado deliberadamente transparente, travestido narrativamente de vingança. É onde entra essa forma de pilhagem biográfica, de "vampirismo compassional" (Forest, 2011, p. 94): arvorar-se o direito de compartilhar com um público leitor a vida real vivida por alguém, ao lado de quem se tomou a decisão unilateral da partilha dessa vida em comum, sob a forma narrativa indefinida de um testemunho elasticamente deformado em prol de uma verdade literária, de um efeito estético, de um postulado autorrefletido sobre a vida e a escrita. Do ponto de vista estritamente estético, não se pode negar o impacto devastador que essa literatura pode ter sobre o leitor. ${ }^{27}$

Testemunho do processo de escrita, a obra ganha força pela indefinição de seu estatuto. Pois, se a autoficção usa frames específicos de como narrar a vida, são os da intimidade: eles comunicam ao leitor a dúvida e a solução:

\footnotetext{
${ }^{26}$ Tal defesa do literário, de forma irônica ou sutil, é comum na autoficção. Vide Coetzee, Roth, Vila-Matas, Doubrovsky. Outros, como Angot e Lísias, preferem o libelo passional, uma defesa da literatura feita aos moldes de Rousseau nas Confissões. Tal libelo como forma parece ensejar a vingança como tema. E vingança vem justificada pelo martírio. No caso de Lísias, o narrador (que, a essa altura, não se distancia do autor para qualquer leitor minimamente engajado) esmiúça seu sofrimento, sua humilhação. Como num "linchamento simbólico (Forest, 2011, p. 90), no caso autoinfligido, o narrador se despe diante do leitor, "em carne-viva", na expressão de Lísias. Mas o efeito desse linchamento só se completa com a verificação real, e sua "reduplicação" em forma de literatura, na qual o autor-narrador-personagem coroa seu martírio com o discurso do real, mesmo que tornando-se um "simulacro de si mesmo" (Forest, 2011, p. 90).

${ }^{27}$ Porque não estamos nos referindo apenas à literatura de testemunho ou ao movimento ao encontro da palavra verificável do eu vivido no lastro da grande história universal (vide o Holocausto em Imre Kertész ou Jorge Semprun, a formação de Israel em Amós Oz, o Apartheid em Coetzee), mas, sim, ao relato íntimo, de outra forma interditado ao estranho leitor, de uma vida real, a vida de um escritor e a de pessoas comuns ligadas a ele (o filho do narrador de Cristóvão Tezza, em O filho eterno; a família e os amigos judeus de Michel Laub, em Diário da queda; e, claro, com mais intensidade, a ex-mulher jornalista do narrador Ricardo Lísias no livro do escritor Ricardo Lísias, Divórcio.
} 
não importa, leitor, quanto há de verdade ou ficção no que se lê, importa apenas que você veja, ouça, sinta o verdadeiro da vida. Quem garante tal efeito, sua eficiência, é a instância supranarrativa do autocomentador. Lísias, autornarrador-personagem que comenta sua vida e sua escrita dentro e fora dos romances, perfaz uma metanarração ad infinitum.

"Divórcio é um livro repetitivo", diz o narrador-comentador (Lísias, 2013a, p. 173). A partir da página 184, o grau de comentário aumenta, ganha ares de libelo ético e estético:

A falência da ética, inteiramente soterrada pelo interesse financeiro, causa ditaduras tão violentas quanto as antigas. Como elas aparecem acompanhadas por uma variação estranha da palavra liberdade, ficam mais difíceis de ser identificadas. Vou dar um exemplo: e a minha liberdade, depois de ter testemunhado e vivido tudo isso sobre o meu corpo $n u$, de escrever um livro e ser o mais claro e direto possivel? Acredito que a arte deva desafiar qualquer tipo de poder. Divórcio é a minha profissão de fé contra essas neoditaduras (Lísias, 2013a, p. 184, grifo nosso).

"Profissão de fé" é como o narrador vê o romance que denuncia a falta de ética com um posicionamento sobre a privacidade de outra pessoa eticamente indefensável, a não ser em nome da autonomia intocável da arte. Defende-se, assim, que a autoficção (ao contrário do que alguns teóricos sugerem) não é uma escrita do testemunho, mas uma literatura com propósito além do eu, voltada ao ataque a qualquer formalismo, à defesa intransigente de uma liberdade ontologicamente assegurada. $\mathrm{O}$ comentário sobre a literatura que pilha a realidade torna-se, além de uma técnica com efeito estético, uma defesa do livro. ${ }^{28} \mathrm{E}$ não há melhor defesa do literário do que o ataque à própria obra, via uma performance de isenção que aproxima o narrador de um humilde camarada.

Não reconheço a inverossimilhança como um defeito de Divórcio. Mas hoje, treze meses depois de começar a escrevê-lo e portanto dezessete de ter lido o diário, encontro alguns problemas no livro. Já os pressentia durante a redação e deixei o décimo terceiro capítulo para comentá-lo (Lísias, 2013a, p. 199).

\footnotetext{
${ }^{28}$ Defesa que, como se viu, é feita paralelamente em discursos midiáticos e no próprio livro. A ver o trecho a seguir: "Divórcio não é um livro de jornalismo, não tem fontes, não usa offs, as fotos são de arquivos familiares e o autor do livro, responsável por todas as linhas, é Ricardo Lísias" (Lísias, 2013a, p. 196).
} 
O narrador elenca tais erros e faz um mea-culpa metacrítico (Lísias, 2013a, p. 203), além de fazer do $13^{\circ}$ capítulo uma reflexão sobre os defeitos da obra, como se o comentário pudesse definir seu lugar na recepção do leitor e antecipar respostas a quaisquer perguntas. ${ }^{29} \mathrm{E}$ explica, didaticamente, como o livro (um livro imaginário ou o livro que o leitor tem em mãos?) serviu como terapia. “O fato é que Divórcio não recuperou apenas o meu equilíbrio emocional. O livro e as corridas me trouxeram uma pele nova e agora quero me tornar uma pessoa melhor" (Lísias, 2013a, p. 210). Tais frases entregam ao leitor a noção de que o livro é fruto de um projeto de vingança e cura traduzido em literatura. ${ }^{30}$

E, quando o leitor pode se dar finalmente por satisfeito com a estratégia do livro, Lísias complica ainda mais o estatuto enunciativo, adicionando uma instância extra entre quem vive, quem narra, quem assina, quem fala: ${ }^{31}$

Parece que estava nervoso no fragmento anterior. Ao contrário, planejei tudo para que, em um crescendo de indignação, o narrador chegasse à conclusão final. Eu e ele nos descolamos. Fiz até uma pequenina tabela com as características do narrador que Divórcio foi constituindo enquanto eu apaziguava meu trauma. Ela vai ter pouco uso, porém: no próximo capítulo, o narrador sai para que Ricardo Lísias volte à cena (Lísias, 2013a, p. 217).

E o que dizer do trecho seguinte:

O que faz então com que Divórcio seja um romance? Em primeiro lugar, Excelência, é normal hoje em dia que os autores misturem à

\footnotetext{
${ }^{29}$ Vide os trechos: "O livro tem ainda outros problemas. Alguns trechos são confusos e a oscilação, obviamente proposital, entre o discurso passado e em menor quantidade outro no presente pode prejudicar a leitura" (p. 207); "Na última leitura achei alguns parágrafos mal escritos e vários confusos. Não sei o que o editor vai achar deles" (p. 213); "Durante o auge da minha raiva, fui injusto com os 'jornalistas'. Generalizei para toda a categoria o comportamento de um grupo específico” (p. 215).

${ }^{30}$ Verter em narrativa literária uma experiência de vida seria a função dessa literatura engajada em si mesma. Vide os trechos: "O livro vai chegando ao fim e, mesmo sem ter conseguido contornar todos os defeitos que enxergo nele, sinto-me forte. Se o meu objetivo inicial era deixar para trás todo o mal-estar que senti ao ler o diário, Divórcio é um romance bem-sucedido" (p. 212); e "Estou curioso com o que os leitores vão achar. Provavelmente, alguns acabem julgando um absurdo a exposição que fiz da minha ex-mulher. A eles, terei uma resposta pronta: é uma personagem. Para ser sincero, acredito nisso" (p. 214).

${ }^{31}$ Aqui se abre novamente uma bifurcação perigosa: se o narrador se descola do eu Ricardo Lísias, esse seria o autor falando intradiegeticamente? Ou a sentença iria apenas ao encontro da tese da fragmentação do eu que narra, da complexidade da identidade narrativa?
} 
trama ficcional elementos da realidade. Depois há um narrador visivelmente criado e diferente do autor (Lísias, 2013a, p. 217-218).

Mesmo que Lísias tente uma última instância desvencilhar-se do jogo estatutário que provocou, dirigindo-se a um suposto juiz e explicando o procedimento que assumiu no romance, como se vê, já não é mais possível separar artificialmente o que, durante mais de 200 páginas, caminhou (ou correu) de forma indissociável. E se, separado for, esse outro ser que diz eu em nome de Ricardo Lísias, se não o narrador, só pode ser o autor - o que põe a pá de cal no estatuto novelesco do romance.

\section{A suspensão ética como projeto literário}

Parece-me sugestivo que a crítica acadêmica tenha se preocupado tanto com as filigranas conceituais do que é ou não autoficção e até tenha deitado alguma atenção ao leitor, pensando o pacto de leitura e o estatuto de verdade do texto, sem atentar para as referências de fato, a ver, pessoas de carne e osso e suas memórias ou vidas cotidianas - e digo isso não em termos moralistas (afinal, estamos falando de literatura), mas em termos pragmáticos, em relação à leitura. Pois chamar um leitor de voyeur não dá conta da especificidade estética que surge de uma apropriação ética de tal monta.

Alguns críticos, após criar seus neologismos, creem resolver o problema das "zonas de sensibilidade" exigindo um "pacto de leitura claro" (Schmitt, 2010, p. 77). Alberca gasta 300 páginas falando da onomástica autor-narrador-personagem, do desdobramento do autor, da deriva do sujeito, da desfragmentação do eu, do jogo dialético entre íntimo e público - mas quase esquece a concretude das referências reais humanas, que existem não só na memória do autor-narrador como entidade enunciativa como numa realidade que só a elas lhes toca. Apenas no subcapítulo "mea-culpa", o autor vê com nitidez o problema deontológico escondido no pressuposto da indefinição ética do estatuto movediço de nomes, documentos, situações reais. Frente à "calculada estratégia" repleta de afirmações contraditórias, mais uma vez, seria o leitor que teria de dar respostas, resolvendo "a incerteza do relato" (Alberca, 2007, p. 297, tradução nossa).

Alberca ignora que esse suplemento de incerteza ética advindo da incerteza estatutária é o que seduz o leitor. Num paradoxo pautado pela "reivindicação de irresponsabilidade" (Alberca, 2007, p. 278, tradução 
nossa), o autor-narrador-personagem, referencial e homônimo, mas fragmentado, surge como continuação às avessas do protagonista becketiano, que se descasca rumo ao nada existencial: ao se desconstruir, essa voz se reafirma como entidade narrativa capaz de sustentar ética, estética e ontologicamente a indefinição do estatuto e do pacto. Além disso, esse ser que se dessubjetiviza legitimando-se, retirando de seus ombros e dos do leitor qualquer sobrepeso ético, faz o mesmo com aqueles seres que com ele conviveram numa instância prénarrativa, aludida pela indefinição estatutária. Junto a essa "calculada estratégia de degradação do próprio eu" (Alberca, 2007, p. 279, tradução nossa) jaz a degradação do direito ao silêncio dos outros. Mesmo concordando que deve haver limites às histórias de cunho biográfico (Eakin, 1999, p. 161), não me cabe analisar o compromisso ético do escritor. Mas é cabal pensar como uma literatura que borra seu estatuto ficcional e oferece uma narrativa ambígua deliberadamente concorre a um efeito estético que passa por um esgarçamento ético. ${ }^{32}$ Vejo essa relação entre autor-narrador-protagonista e leitor como um jogo entre o narcisista engajado na aventura de estabelecer os limites possíveis da literatura que brota de si e o voyeur que assiste à tentativa de tatear as fronteiras do aceitável sem envolver-se eticamente com ela, ainda que participando ativamente da empreitada - é ele quem concretiza a potência em ato. Entre ambos, surge um pacto mefistofélico, pelo qual seguir na obra é aceitar a indefinição estatutária e a consequente elasticidade ética contidas nessa invasão de limites narrativos calcados no real e singular, no existente verídico e único, na vida real ficcionalizada como possibilidade estética.

Penso que esse pacto anfíbio, mutante, que inquere o leitor a seguir os passos de um voyeurismo eticamente delicado, traga-lhe também a possibilidade de uma hermenêutica do ethos da obra (Ricoeur, 1990/2010, p. 236). Mas, mesmo que essa suspensão ética seja momentânea (como seria a suspensão da descrença), mesmo que o "eu-ipse" seja retomado por uma identidade narrativa não só fora do texto como longe do livro e

\footnotetext{
${ }^{32}$ Ao analisar os limites entre ética e estética e entre fato e ficção na obra problemática de Philip Roth, Durantaye se pergunta: "o que se pode fazer nesses casos em que somos incapazes de fazer tal distinção - onde parece ser parte do projeto do autor tornar tal distinção inválida?" (Durantaye, 2010 , p. 330). Sua resposta é que, no caso de Roth, o leitor talvez possa usar a própria prática do autor, sua "experimentação em intercambiar as fronteiras entre sua vida e sua obra para seus próprios propósitos", em busca do próprio sentido da relação entre ética e julgamento estético (Durantaye, 2010, p. 330).
} 
distanciada da voz narrativa, e que o mundo do texto seja reconfigurado pelo mundo do leitor, é ela, a suspensão, que o atrai.

Esse espetáculo de execração pública alheia a partir do direito de narrar o real como ficção não é um suplemento de verdade qualquer. Ao incorporar todos os elementos do texto elencados até aqui, o leitor estabelece uma relação de cumplicidade com o autor, pautada seja pela negação ou pela aceitação da proposta ética subjacente ao postulado estético e sua concretização literária. O romance convoca o leitor a um pacto de cumplicidade que efetua, na leitura, a mesma defesa da absoluta autonomia literária contida na escrita, como prática e como tema. Seguindo na leitura sob tal pacto indeciso oferecido de início, a parte que cabe ao leitor, de salvar a literatura de seus algozes moralistas, não é pequena.

Veja-se a continuação do trecho em que o narrador defende sua escrita e sua "profissão de fé" para livrar a literatura atual da "falência ética" da crítica:

Sempre me irritaram os romancistas que pretensamente "retratariam o ponto de vista do outro". Aqueles que dão espaço para posições contrárias apresentam vários pontos de vista e relativizam tudo. Parte da teoria literária os tomou como grandes artistas justamente por conta disso (Lísias, 2013a, p. 184).

Se o leitor, prestes a terminar o livro - já detentor não apenas dos elementos paratextuais (e talvez dos epitextuais) à mão e ciente da homonímia da voz narrativa e do compartilhamento da biografia entre autor e narrador -, recebe tal afirmação do autocomentador sobre a lisura e a importância do procedimento de escrita que sua performance engendra, creio que ele se sente parte de um projeto literário que não se concretizaria sem ele: percebe-se fiador da empreitada da escrita como ato literário que tem ação sobre a vida. Fecha-se, assim, um ciclo de fruição estética calcada em um embate de ordem ética, marcada pelo estatuto ficcional eternamente indefinido. Continuar a leitura, quando os signos da operação ético-estética da autoficção foram explicitados, é aceitar um acordo tácito eticamente situado.

O romance conta a história da vida de um escritor, mas a história que chama o leitor a decidir e que, em última instância, qualifica o livro como experiência ulteriormente interessante, é a da própria literatura como ato, seus limites, sua conformação estética que desafia a ética em nome da 
arte. É quando o pacto com o diabo se efetua que a autoficção concretiza sua proposta de autonomia absoluta de escrita do real como ficção.

\section{Referências}

ALBERCA, Manuel (2007). El pacto ambiguo. De la novela autobiográfica a la autoficcion. Madrid: Biblioteca Nueva.

ANGOT, Christine (2011). Les petits. Paris: Flammarion.

BARTHES, Roland (2004). O rumor da língua. Tradução de Mario Laranjeira. 2. ed. São Paulo: Martins Fontes.

BLANCKEMAN, Bruno (2000). Les récits indécidables: Jean Echenoz, Hervé Guibert, Pascal Quignard. Lille: Presses Universitaires du Septentrion.

BURGELIN, Claude; GRELL, Isabelle (2010). Autofiction(s). Actes du colloque de Cerisy-la-Salle. Lyon: PUL.

DOUBROVSKY, Serge (1977). Fils. Paris: Galilée.

DURANTAYE, Leland de la (2010). How to read Philip Roth, or the ethics of fiction and the aesthetics of fact. The Cambridge Quarterly, Oxford, v. 39, n. 4, p. 303-330, Dec.

EAKIN, Paul John (2004). The ethics of life writing. Ithaca; Londres: Cornell University Press.

FOREST, Philippe (Ed.) (2011). Je \& moi. Paris: Gallimard. (La Nouvelle Revue Française, n. 598).

GALÍNDEZ-JORGE, Verónica (2009). Fogos de artifício: Flaubert e a escritura. Cotia: Ateliê.

GALLE, Helmut (2011). O gênero autobiográfico: possibilidade(s), particularidades e interfaces. Tese (Livre Docência) - Universidade de São Paulo, São Paulo.

GASPARINI, Philippe (2008). Autofiction: une aventure du langage. Paris: Seuil.

GASPARINI, Philippe (2016). Poétiques du Je. Du roman autobiographique à l'autofiction. Lyon: PUL.

GENETTE, Gerard (1987). Seuils. Paris: Seuil. (Col. Poétique).

GENETTE, Gerard (1991). Fiction et diction. Paris: Seuil. 
KLINGER, Diana (2007). Escritas de si, escritas do outro: o retorno do autor e a virada etnográfica. Rio de Janeiro: 7 Letras.

LEJEUNE, Philippe (1975). Le pacte autobiographique. Paris: Seuil.

LEJEUNE, Philippe (2005). Signes de vie: le pacte autobiographique 2. Paris: Seuil.

LÍSIAS, Ricardo (2013a). Divórcio. Rio de Janeiro: Alfaguara.

LÍSIAS, Ricardo (2013b). Em “Divórcio", o drama pessoal é ponto de partida para a ficção. Entrevista a Luciano Trigo. G1, Blog Máquina de Escrever, Rio de Janeiro, 8 set.

LÍSIAS, Ricardo (2016). O que os fortes queriam? Uma análise de O que é isso, companheiro? e Os carbonários. Estudos de Literatura Brasileira Contemporânea, Brasília, n. 48, p. 229-246.

MONTEIRO, Pedro Meira (2013). Como falar a verdade? A ética da ficção em Divórcio, de Ricardo Lísias. Celeuma.

RICOUER, Paul (1990/2010). O si mesmo como outro. São Paulo: WMF Martins Fontes.

SCHMITT, Arnaud (2010). Je réel / Je fictif: au-delà d'une confusion postmoderne. Toulouse: Presses universitaires du Mirail. (Collection Cribles).

SCHWARZ, Daniel (2001). A humanistic ethics of reading. In: DAVIS, Todd F.; WOMACK, Kenneth (Dir.). Mapping the ethical turn. A reader in ethics, culture, and literary theory. Charlottesville: University Press of Virginia.

Recebido em 30 de junho de 2016.

Aprovado em 31 de outubro de 2016.

\section{resumo/abstract/resumen}

\section{Pacto com o diabo: Divórcio, de Ricardo Lísias, como manual para compreender a autoficção contemporânea}

Willian Vieira

Propõe-se que Divórcio, de Ricardo Lísias, ao expor didaticamente todo o ferramental da chamada autoficção, funciona como manual para apreender o gênero e pensar sua especificidade: a ver, o jogo entre a indefinição do estatuto ficcional e a dimensão ética de uma recepção orientada pela performance autoral dentro e fora do texto. A partir daí, pode-se pensar o papel dessa 
incerteza estatutária e do jogo performático com o leitor na defesa, pelo romance, de uma autonomia absoluta do fazer literário.

Palavras-chave: autoficção, estatuto ficcional, performance, leitor, ética, Ricardo Lísias.

\section{A pact with the devil: Divórcio, by Ricardo Lísias, as a manual to understand autofiction today}

Willian Vieira

The article analyses how Divórcio, by Ricardo Lísias, can be seen as a manual to understand the specificity of autofiction. The book features all the "tools" that characterize the genre. It delineates, didactically, the play between the indefinite fictional status and the ethical dimension of a reception based on the author's performance, within and outside of the text itself. From this uncertainty regarding the status of the text and the performatic play, in which the reader is an active player, the novel allows the author to defend a new autonomy of the literary practice.

Keywords: autofiction, fictional status, performance, reader, ethics, Ricardo Lísias.

\section{Un pacto con el diablo: Divórcio, de Ricardo Lísias, como un manual para comprender la autoficcion contemporánea}

Willian Vieira

El articulo analiza cómo Divórcio, de Ricardo Lísias, puede ser entendido como un verdadero manual para entender a la autoficción en lo que tiene ésta de más singular. Al compartir didácticamente con el lector todos los mecanismos del género, tales como el juego de incertidumbre estatutaria del texto y la dimensión ética de una recepción basada en el performance autoral dentro y fuera del texto, la obra permite aún vislumbrar una nueva defensa de la autonomía absoluta del quehacer literario.

Palabras clave: autoficcion, estatuto ficcional, performance, lector, ética, Ricardo Lísias. 